\title{
Środki działające podobnie do alkoholu a aspekty bezpieczeństwa w ruchu drogowym na terenie Pomorza Zachodniego*
}

\section{Substances acting like ethanol and aspects of road traffic safety in the West Pomeranian province in Poland}

\author{
1 Pomorski Uniwersytet Medyczny, Zakład Toksykologii Klinicznej i Sądowej, al. Powstańców Wlkp. 72, 70-111 Szczecin \\ Pomeranian Medical University in Szczecin, Department of Clinical and Forensic Toxicology \\ ${ }^{2}$ GENPALT Poland sp. z o.o., ul. Mielecka 56, 70-737 Szczecin \\ ${ }^{3}$ Sąd Rejonowy Szczecin-Centrum w Szczecinie, ul. Kaszubska 42, 70-227 Szczecin \\ District Court Szczecin Center in Szczecin \\ $\triangle$ bpotocka@pum.edu.pl
}

Barbara Potocka-Banaś ${ }^{1 凶}$, Michał Wojtyś2 ${ }^{2}$ Tomasz Banaśs ${ }^{3}$ Urszula Semeniuk${ }^{1}$, Krzysztof Borowiak $^{1}$

\begin{abstract}
Introduction: Nowadays automotive transport is the basis for the efficient functioning of society, thus road safety, which is dependent on many factors such as the technological condition of roads, weather or traffic regulations, has a substantial impact on its performance. It should also be emphasized that traffic safety depends primarily on the mental psycho-organic status of drivers.

The presented retrospective study describes drugs and medicines known to act similarly to ethanol, and which can be detected in the blood of drivers.

The study aimed to analyze statistical data on driver blood samples that were tested for the presence of substances acting like ethanol. The analysis focused on samples collected in the period 2011-2015 in the West Pomeranian province in Poland.

Materials and methods: During the analyzed period, more than 3069 of toxicological tests were performed on driver blood samples at the Department of Clinical Toxicology and Forensic Medicine of the Pomeranian Medical University in Szczecin (Poland).
\end{abstract}

Results: Based on the blood test results obtained in the period 2011-2015, the studies revealed the presence of substances acting like ethanol: 9delta-tetrahydrocannabinol ( $9 \Delta \mathrm{THC}$ ), amphetamine, methamphetamine, 3,4-methylenedioxymethamphetamine, cocaine, opiates and benzodiazepines. Moreover, the percentage of drivers whose blood samples revealed the presence of such substances increased steadily along with the simultaneous increase in the percentage of road users under the influence of the detected substance.

Within the analysis, the presence of $9 \Delta \mathrm{THC}$ in the blood of drivers decreased from $80.45 \%$ to $44.13 \%$, whilst the percentage of drivers with the presence of amphetamines increased from $16.43 \%$ to $46.85 \%$, and was the most commonly detected psychoactive substance in 2015 .

Conclusions: The percentage of drivers whose blood samples revealed the presence of opiates, cocaine and benzodiazepines in the analyzed period remained at a constant low level of 5.24\% in contrast to the number of drivers detected with amphetamines or $9 \Delta \mathrm{THC}$

Keywords: road safety; substances acting like ethanol.

\section{ABSTRAKT}

Wstęp: Komunikacja motoryzacyjna obecnie jest podstawą sprawnego funkcjonowania społeczeństwa. Niebagatelny wpływ na jej działanie ma bezpieczeństwo, które jest zależne od wielu czynników, jak stan nawierzchni, pogoda czy przepisy ruchu drogowego. Podkreślić należy, że bezpieczeństwo na drogach zależy jednak przede wszystkim od sprawności psychofizycznej kierującego. W pracy przedstawiono środki działające podobnie do alkoholu wykrywane we krwi kierowców. Celem pracy była analiza statystyczna danych uzyskanych na podstawie badań krwi zabezpieczonej od kierowców w latach 2011-2015 na terenie województwa zachodniopomorskiego w kierunku obecności środków działających podobnie do alkoholu.

Materiały i metody: Przeanalizowano 3069 ekspertyz wykonanych w latach 2011-2015 w Zakładzie Toksykologii Klinicznej i Sądowej Pomorskiego Uniwersytetu Medycznego w Szczecinie.
\end{abstract}

Wyniki: Na podstawie uzyskanych wyników stwierdzono we krwi kierowców obecność środków działających podobnie do alkoholu, jak: 9delta-tetrahydrokannabinol (9DTHC), amfetamina, metamfetamina, 3,4-metylenodioksymetamfetamina, kokaina, opiaty i benzodiazepiny. Ponadto w latach 2011-2015 stale wzrastał odsetek kierowców, w próbkach krwi których stwierdzono obecność środków działających podobnie do alkoholu, wraz z jednoczesnym wzrostem procentowym liczby uczestników ruchu drogowego będących pod wpływem wykrytej substancji. Przeprowadzona analiza wykazała, że w omawianym okresie obecność $9 \Delta \mathrm{THC}$ we krwi kierowców stopniowo malała z początkowych $80,45 \%$ do $44,13 \%$ w ostatnim ocenianym roku. Natomiast w tym samym czasie wzrósł odsetek kierowców, u których stwierdzono obecność amfetaminy z $16,43 \%$ do $46,85 \%$ - była to najczęściej wykrywana substancja psychoaktywna w $2015 \mathrm{r}$.

\footnotetext{
* Artykuł na podstawie pracy magisterskiej Michała Wojtysia pt. „Nowe substancje psychoaktywne a bezpieczeństwo ruchu drogowego w latach 2011-2015”. Promotor dr n. med. Barbara Potocka-Banaś. Oryginał obejmuje: 63 stron, 13 rycin, 9 tabel, 7 wykresów, 59 pozycji piśmiennictwa.
} 
Wnioski: W badanym okresie w odróżnieniu od liczby kierowców, u których wykryto amfetaminę oraz 9DTHC, odsetek uczestników ruchu drogowego, we krwi których stwierdzono obecność opiatów, kokainy oraz benzodiazepin, znajdował się na stałym, względnie niskim poziomie (łącznie $5,24 \%$ ).

Słowa kluczowe: bezpieczeństwo w ruchu drogowym; środki działające podobnie do alkoholu.

\section{WSTĘP}

Przez wiele lat jedynym środkiem odurzającym penalizowanym w prawie, którego wpływ na bezpieczeństwo ruchu drogowego rozpatrywano pod względem medyczno-prawnym, był alkohol etylowy. W ostatnich latach w praktyce ekspercko-orzeczniczej odnotowuje się wyraźny wzrost liczby uczestników ruchu drogowego znajdujących się pod wpływem lub w stanie po użyciu środków działających podobnie do alkoholu, a wyodrębnianych stopniowo w przepisach wykonawczych (kodeks karny i kodeks wykroczeń) po $2005 \mathrm{r}$.

Obecnie zgodnie z rozporządzeniem Ministra Zdrowia z dnia 18 lipca 2014 r. (Dz.U. z 2014 r., poz. 948) środkami działającymi podobnie do alkoholu są: amfetamina i jej analogi (np. metamfetamina, 3,4-metylenodioksymetamfetamina - MDMA) opiaty, kokaina, tetrahydrokannabinol (THC) oraz pochodne benzodiazepiny [1].

Amfetamina jest pochodną fenyloetyloaminy, która działa przez układ współczulny. Powoduje m.in. silne pobudzenie psychoruchowe, rozszerzenie źrenic, zmniejszenie łaknienia, bezsenność. Chroniczne zażywanie może prowadzić dodatkowo do zmian osobowości, wzrostu agresji oraz zachowań psychotycznych [2].

Syntetycznym analogiem amfetaminy jest MDMA, która działa przez układ adrenergiczny, dopaminergiczny i serotoninergiczny. Wywołuje pobudzenie i euforię, wzrost napięcia emocjonalnego, niepokój, nadwrażliwość na bodźce zewnętrzne, halucynacje, ataki paniki, rozszerzenie źrenic, podwójne widzenie, zaburzenie akomodacji, nadwrażliwość na światło, suchość w jamie ustnej [3, 4, 5].

Przeprowadzone liczne badania symulatorowe jednoznacznie wykazały, że kierowcy, którzy zażywali amfetaminę i związki pochodne, prowadzą pojazdy brawurowo, znacznie przekraczają dozwoloną prędkość, nie zatrzymują się na czerwonym świetle itp. Zaobserwowano także skłonność do nieprawidłowego sygnalizowania manewrów drogowych. Wysokie dawki amfetaminy i jej pochodnych w połączeniu z alkoholem znacząco podnosiły ryzyko podejmowania przez kierowców zachowań stwarzających potencjalne ryzyko wypadków na drodze [2].

Główną substancją psychoaktywną z grupy kannabinoidów, zawartą w konopiach indyjskich, jest 9delta-tetrahydrokannabinol ( $9 \Delta \mathrm{THC}$ ). Oddziałuje on przez receptory kannabinoidowe CB1 (występujące m.in. w korze mózgu, hipokampie, podwzgórzu, móżdżku, ciałach migdałowatych) oraz CB2 (związane z komórkami układu immunologicznego). Ze względu na różnorodne miejsca występowania tych receptorów $9 \Delta \mathrm{THC}$ wykazuje szeroki wachlarz objawów, m.in. poprawę nastroju, wesołkowatość, wyostrzenie zmysłów, wzrost apetytu, wysuszenie błon śluzowych, zaburzenia widzenia, halucynacje, spowolnienie reakcji, stany lękowe, ataki paniki, zaburzenia pamięci krótkoterminowej [2,6].

Przeprowadzone badania symulatorowe wykazały, że zażycie 9 $\Delta$ THC znacząco wydłużało czas reakcji kierowców podczas prowadzenia pojazdów. Przyjęcie dawki poniżej $200 \mu \mathrm{g} / \mathrm{kg}$ masy ciała (m.c.) skutkowało częstą zmianą lokalizacji na pasie ruchu, a także częstszą zmianą odległości w stosunku do innych pojazdów. Natomiast zażycie dawek większych niż $200 \mu \mathrm{g} / \mathrm{kg}$ m.c. powodowało częstsze kolizje na drodze, wydłużony czas reakcji oraz częstsze nieuzasadnione zmiany prędkości. Istotne znaczenie miała również zauważalna nadwrażliwość na światło, szczególnie w porach nocnych [2].

Kokaina jest estrem metylowym benzoiloekgoniny, występującym najczęściej w formie chlorowodorku. Mechanizm działania kokainy polega na blokowaniu transporterów noradrenaliny i dopaminy, co prowadzi do ich zwiększonego stężenia w szczelinach synaptycznych centralnego i obwodowego układu nerwowego. Kokaina wywołuje euforię, silne pobudzenie psychoruchowe, omamy wzrokowe, zaburzenia pamięci, rozszerzenie źrenic, gadatliwość, mowę inkoherentną. Wpływ kokainy na prowadzenie pojazdu jest zbliżony do tego, jaki wywołuje amfetamina [2, 7].

Określenie „opioidy” odnosi się zarówno do syntetycznych opioidów, jak i naturalnych związków opiatowych. Do tej grupy należą m.in. morfina, kodeina czy heroina. Opioidy wiążą się $w$ organizmie z receptorami opioidowymi: $\mu, \kappa$ czy $\delta$. Aktywacja receptora $\mu$ powoduje zwężenie źrenic, euforię, analgezję. Pobudzenie receptora $\kappa$ również wywołuje zwężenie źrenic i analgezję, a także senność i działanie uspokajające. Aktywacja receptora $\delta$ objawia się halucynacjami i urojeniami.

U osób zażywających opioidy obserwuje się spowolnienie reakcji, zaburzenia widzenia i nieprawidłową ocenę rzeczywistości, a więc upośledzenie sprawności psychomotorycznej, co w przypadku kierowców stwarza realne zagrożenie [5, 8].

Pochodne benzodiazepiny (np. diazepam, estazolam, midazolam) obejmują szeroką grupę związków farmakologicznych o działaniu uspokajającym, nasennym, przeciwdrgawkowym i miorelaksacyjnym. Mechanizm działania pochodnych benzodiazepiny nie został dokładnie wyjaśniony; miejscem ich działania jest makromolekularny kompleks obejmujący receptory $\mathrm{GABA}_{\mathrm{A}}$, receptory benzodiazepinowe i kanały chlorkowe. Pochodne benzodiazepiny wywołują m.in. senność, zaburzenia koordynacji ruchowej, ataksję, amnezję następczą, zaburzenia akomodacji, oczopląs. Z powodu tych zaburzeń kierowcy znajdujący się pod wpływem pochodnych benzodiazepiny stwarzają potencjalne zagrożenie w ruchu drogowym [9]. 


\section{MATERIAtY I METODY}

W pracy przedstawiono retrospektywną analizę statystyczną danych na podstawie badań toksykologicznych wykonanych w Zakładzie Toksykologii Klinicznej i Sądowej (ZTKiS) Pomorskiego Uniwersytetu w Szczecinie (PUM) w latach 2011-2015. Analiza obejmowała 3069 ekspertyz materiału biologicznego (krew) pobranego od uczestników ruchu drogowego na terenie województwa zachodniopomorskiego. Badania jakościowe i ilościowe przeprowadzono za pomocą metod analitycznych:

- chromatografii gazowej sprzężonej ze spektrometrią mas (gas chromatography mass spectrometry - GC-MS),

- chromatografii cieczowej sprzężonej z tandemową spektrometrią mas (liquid chromatography mass spectrometryLC-MS).

\section{WYNIKI}

W latach 2011-2015 w ZTKiS PUM wykonano 3069 ekspertyz materiału biologicznego ocenianego pod kątem obecności środków działających podobnie do alkoholu. Materiał był zabezpieczany od kierowców i uczestników ruchu drogowego na terenie województwa zachodniopomorskiego po wcześniejszym zatrzymaniu przez funkcjonariuszy policji. W $2011 \mathrm{r}$. wykonano 533 badania, co stanowiło 17,37\% wszystkich ekspertyz w analizowanym okresie. W 2012 r. wykonano 546 (17,79\%) analiz, w 2013 r. - 624 (20,33\%), w 2014 r. - 618 (20,14\%), a w 2015 r. przeprowadzono 748 (24,37\%) badań (ryc. 1).

W 2011 r. wynik potwierdzający obecność środka działającego podobnie do alkoholu uzyskano u 355 badanych kierowców, co stanowiło $66,60 \%$ wszystkich badań w tym roku. W 2012 r. wynik pozytywny uzyskano w 399 przypadkach $(73,08 \%)$. W 2013 r. wynik dodatni stwierdzono u 409 badanych (65,54\%). Natomiast w 2014 r. wynik dodatni uzyskano w przypadku 510 badanych (82,52\%), a w 2015 r. w 609 przypadkach $(81,42 \%)$ wszystkich wykonanych badań (ryc. 2).

W ocenianym okresie liczba badań przeprowadzanych pod kątem środków działających podobnie do alkoholu systematycznie wzrastała (ryc. 1). Porównując procentowy udział kierowców w zdarzeniach drogowych, u których stwierdzono

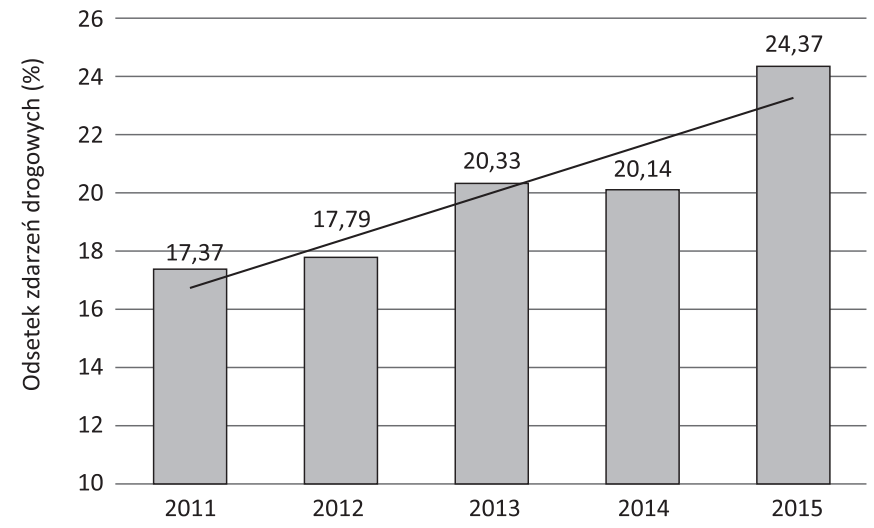

RYCINA 1. Badania przeprowadzone we krwi kierowców na obecność środków działających podobnie do alkoholu w latach 2011-2015 obecność substancji psychoaktywnych, również zaobserwować można tendencję wzrostową, za wyjątkiem 2013 r., gdzie wyniki dodatnie stanowiły tylko 65,54\% przeprowadzonych badań, co było spadkiem o 7,53\% względem poprzedniego roku (ryc. 2).

Analiza danych w odniesieniu do poszczególnych rodzajów środków działających podobnie do alkoholu pozwoliła stwierdzić, że w 2011 r. najczęściej wykrywanym związkiem była $9 \Delta \mathrm{THC}-284(80,45 \%)$. Amfetaminę wykryto natomiast u 16,43\% (58) badanych, opioidy - 7 (1,98\%), kokainę - 3 (0,85\%), a benzodiazepiny - $1(0,28 \%)$. Ze względu na szerokie spektrum leków, które obejmuje grupa benzodiazepin, a także ich podział z uwagi na czas działania przyjęto w każdym przypadku, że kierowcy, u których wykryto benzodiazepiny, znajdowali się pod ich wpływem.

Rozpatrując stężenie 9 $\Delta \mathrm{THC}$ uzyskane w badanej krwi, stwierdzono, że 32,04\% (91) badanych znajdowało się pod wpływem 9 $\Delta \mathrm{THC}$, natomiast w stanie po użyciu znajdowało się 67,96\% (193) badanych.

W przypadku amfetaminy uzyskano odwrócony stosunek - pod wpływem amfetaminy znajdowało się 74,07\% (40) badanych, a 25,94\% (9) było w stanie po użyciu tej substancji psychoaktywnej.

Stężenia opiatów we krwi badanych kierowców wskazywały, że 85,71\% (6) badanych było pod wpływem tych substancji, zaś 14,29\% (1) znajdowało się w stanie po użyciu. W przypadku kokainy wszyscy uczestnicy ruchu drogowego, u których wykryto ten związek (3 badanych), znajdowali się w stanie po użyciu tego środka (tab. 1).

TABELA 1. Środki działające podobnie do alkoholu wykryte we krwi kierowców w 2011 r.

\begin{tabular}{lccc}
$\begin{array}{c}\text { Środek } \\
\text { psychoaktywny }\end{array}$ & $\begin{array}{c}\text { Pod } \\
\text { wptywem }\end{array}$ & Po użyciu & $\begin{array}{c}\text { Odsetek } \\
\text { w roku }\end{array}$ \\
\hline $9 \Delta \mathrm{THC}$ & $32,04 \%$ & $67,96 \%$ & $80,45 \%$ \\
\hline Amfetamina & $68,97 \%$ & $31,03 \%$ & $16,43 \%$ \\
\hline Metamfetamina & $0,00 \%$ & $0,00 \%$ & $0,00 \%$ \\
\hline MDMA & $0,00 \%$ & $0,00 \%$ & $0,00 \%$ \\
\hline Opioidy & $85,71 \%$ & $14,29 \%$ & $1,98 \%$ \\
\hline Kokaina & $0,00 \%$ & $100 \%$ & $0,85 \%$ \\
\hline Benzodiazepiny & $100 \%$ & $0,00 \%$ & $0,28 \%$ \\
\hline
\end{tabular}

9 $\triangle \mathrm{THC}$ - 9delta-tetrahydrokannabinol; MDMA - 3,4-metylenodioksymetamfetamina

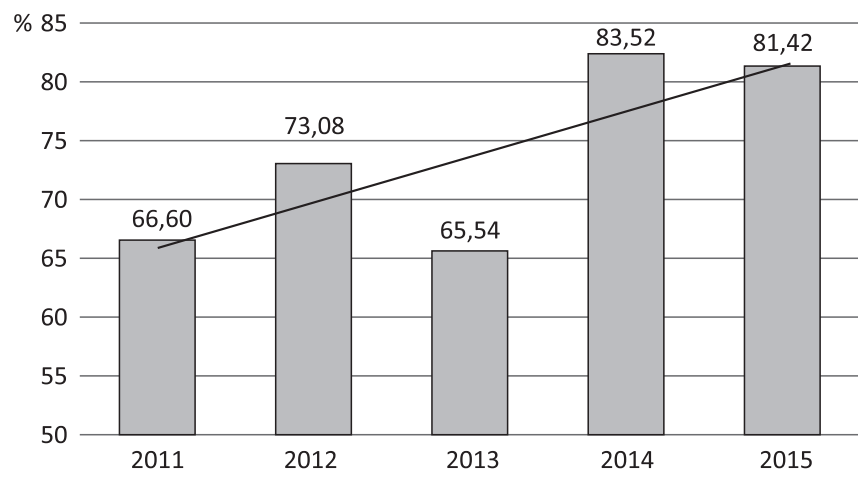

RYCINA 2. Wyniki badań dodatnich we krwi kierowców na obecność środków działających podobnie do alkoholu w latach 2011-2015 
Analiza danych za 2012 r. wykazała, że podobnie jak w roku poprzedzającym najczęściej wykrywanym środkiem działającym podobnie do alkoholu we krwi zabezpieczonej od kierowców był $9 \Delta$ THC, który został stwierdzony we krwi 289 $(72,07 \%)$ badanych kierowców, gdy amfetaminę stwierdzono u 99 (24,69\%). W tym okresie opioidy wykryto u 1,00\% (4), kokainę u 1,50\% (6), a benzodiazepiny u 0,25\% (1) badanych. Przeprowadzone badania wykazały, że 35,99\% (104) badanych znajdowało się pod wpływem 9 $\Delta \mathrm{THC}$, natomiast 64,01\% (185) było w stanie po użyciu tego środka.

W analizowanej grupie 62,63\% (62) badanych było pod wpływem amfetaminy, a 37,37\% (37) w stanie po jej użyciu. Wśród badanych kierowców, we krwi których wykryto opioidy, 75\% (3) znajdowało się pod ich wpływem, a 25\% (1) było w stanie po użyciu (tab. 2).

Analogiczna analiza danych uzyskanych w 2013 r. wykazała ponownie, że najczęściej wykrywanym środkiem był 9 $\mathrm{TTHC}$. Jego obecność stwierdzono u 66,76\% (249) badanych. Natomiast amfetaminę wykryto w przypadku 29,76\% (111) badanych. Opioidy potwierdzono we krwi 0,80\% (3) badanych, kokainę 1,07\% (4), benzodiazepiny - 0,54\% (2).

Rozpatrując dane pod kątem uzyskanych stężeń 9 $\Delta \mathrm{THC}$, stwierdzono, iż pod wpływem 9 $\Delta$ THC znajdowało się 32,53\% (81) badanych, natomiast w stanie po użyciu było 67,47\% (168). Pod wpływem amfetaminy było 74,77\% (83) badanych, zaś stan po jej użyciu stwierdzono u 25,23\% (28) badanych. Wszyscy kierowcy, u których wykryto opioidy oraz kokainę, znajdowali

TABELA 2. Środki działające podobnie do alkoholu wykryte we krwi kierowców w 2012 r.

\begin{tabular}{lccc} 
Środek psychoaktywny & $\begin{array}{c}\text { Pod } \\
\text { wpływem }\end{array}$ & Po użyciu & $\begin{array}{c}\text { Odsetek } \\
\text { w roku }\end{array}$ \\
\hline $9 \Delta \mathrm{THC}$ & $35,99 \%$ & $64,01 \%$ & $72,43 \%$ \\
\hline Amfetamina & $62,63 \%$ & $37,37 \%$ & $24,81 \%$ \\
\hline Metamfetamina & $0,00 \%$ & $0,00 \%$ & $0,00 \%$ \\
\hline MDMA & $0,00 \%$ & $0,00 \%$ & $0,00 \%$ \\
\hline Opioidy & $75,00 \%$ & $25,00 \%$ & $1,00 \%$ \\
\hline Kokaina & $33,33 \%$ & $66,67 \%$ & $1,50 \%$ \\
\hline Benzodiazepiny & $100 \%$ & $0,00 \%$ & $0,25 \%$ \\
\hline
\end{tabular}

9 $\triangle \mathrm{THC}$ - 9delta-tetrahydrokannabinol; MDMA - 3,4-metylenodioksymetamfetamina

TABELA 3. Środki działające podobnie do alkoholu wykryte we krwi kierowców w 2013 r.

\begin{tabular}{lccc}
\multicolumn{1}{c}{$\begin{array}{c}\text { Substancja } \\
\text { psychoaktywna }\end{array}$} & $\begin{array}{c}\text { Pod } \\
\text { wptywem }\end{array}$ & Po użyciu & $\begin{array}{c}\text { Odsetek } \\
\text { w roku }\end{array}$ \\
\hline $9 \Delta \mathrm{THC}$ & $32,53 \%$ & $67,47 \%$ & $66,76 \%$ \\
\hline Amfetamina & $74,77 \%$ & $25,23 \%$ & $29,76 \%$ \\
\hline Metamfetamina & $100,00 \%$ & $0,00 \%$ & $1,07 \%$ \\
\hline MDMA & $0,00 \%$ & $0,00 \%$ & $0,00 \%$ \\
\hline Opioidy & $0,00 \%$ & $100 \%$ & $0,80 \%$ \\
\hline Kokaina & $0,00 \%$ & $100 \%$ & $1,07 \%$ \\
\hline Benzodiazepiny & $100 \%$ & $0,00 \%$ & $0,54 \%$ \\
\hline
\end{tabular}

9 $\triangle \mathrm{THC}$ - 9delta-tetrahydrokannabinol; MDMA - 3,4-metylenodioksymetamfetamina się w stanie po użyciu tych substancji. Stanowili oni odpowiednio $0,80 \%$ i 1,07\% (tab. 3).

Również analiza danych za 2014 r. potwierdziła stałą tendencję, zgodnie z którą 9 $\Delta$ THC był najczęściej wykrywanym środkiem działającym podobnie do alkoholu we krwi kierowców 49,68\% (233) badanych. Amfetaminę stwierdzono u 42,64\% (200) badanych. Ponadto, w przeciwieństwie do poprzedzających lat, w 2014 r. wykryto metamfetaminę we krwi 13 (2,77\%) badanych oraz MDMA w przypadku 0,85\% (4) badanych. Opioidy wykryto we krwi 0,64\% (3) badanych, kokainę - 1,71\% (8). Benzodiazepiny stwierdzono we krwi 1,71\% (8) badanych, co stanowiło wyraźny wzrost w porównaniu z poprzedzającym okresem. Pod wpływem 9 $\Delta$ THC znajdowało się 48,50\% (113) badanych, a 51,50\% (120) było w stanie po użyciu tego związku.

Pod wpływem amfetaminy było 83,00\% (166) badanych, a 17,00\% (34) było po jej użyciu. Rozpatrując natomiast stężenia pochodnych amfetaminy, stwierdzono, że 84,62\% (11) badanych znajdowało się pod wpływem metamfetaminy, a 15,38\% (2) było w stanie po jej użyciu, gdy jednocześnie wszyscy kierowcy, u których stwierdzono obecność MDMA (0,85\%), znajdowali się pod wpływem tej substancji. Analogiczną sytuację zaobserwowano w przypadku kierowców, u których stwierdzono obecność opiatów $(0,64 \%)$ - tabela 4 .

W odróżnieniu od poprzednich lat w 2015 r. najczęściej wykrywanym środkiem działającym podobnie do alkoholu była amfetamina, którą stwierdzono u 264 (46,98\%) badanych . Natomiast w przypadku $248(44,13 \%)$ badanych

TABELA 4. Środki działające podobnie do alkoholu wykryte we krwi kierowców w 2014 r.

\begin{tabular}{lccc}
$\begin{array}{c}\text { Substancja } \\
\text { psychoaktywna }\end{array}$ & $\begin{array}{c}\text { Pod } \\
\text { wptywem }\end{array}$ & Po użyciu & $\begin{array}{c}\text { Odsetek } \\
\text { w roku }\end{array}$ \\
\hline $9 \Delta \mathrm{THC}$ & $48,50 \%$ & $51,50 \%$ & $49,68 \%$ \\
\hline Amfetamina & $83,00 \%$ & $17,00 \%$ & $42,64 \%$ \\
\hline Metamfetamina & $84,62 \%$ & $15,38 \%$ & $2,77 \%$ \\
\hline MDMA & $100 \%$ & $0,00 \%$ & $0,85 \%$ \\
\hline Opioidy & $100 \%$ & $0,00 \%$ & $0,64 \%$ \\
\hline Kokaina & $12,50 \%$ & $87,50 \%$ & $1,71 \%$ \\
\hline Benzodiazepiny & $100 \%$ & $0,00 \%$ & $1,71 \%$ \\
\hline
\end{tabular}

9 $\triangle \mathrm{THC}$ - 9delta-tetrahydrokannabinol; MDMA - 3,4-metylenodioksymetamfetamina

TABELA 5. Środki działające podobnie do alkoholu wykryte we krwi kierowców w 2015 r.

\begin{tabular}{lccc}
\multicolumn{1}{c}{$\begin{array}{c}\text { Substancja } \\
\text { psychoaktywna }\end{array}$} & $\begin{array}{c}\text { Pod } \\
\text { wptywem }\end{array}$ & Po użyciu & $\begin{array}{c}\text { Odsetek } \\
\text { w roku }\end{array}$ \\
\hline $9 \Delta \mathrm{THC}$ & $57,26 \%$ & $42,74 \%$ & $44,13 \%$ \\
\hline Amfetamina & $88,26 \%$ & $11,74 \%$ & $46,98 \%$ \\
\hline Metamfetamina & $93,33 \%$ & $6,67 \%$ & $2,67 \%$ \\
\hline MDMA & $58,33 \%$ & $41,67 \%$ & $2,14 \%$ \\
\hline Opioidy & $50,00 \%$ & $50,00 \%$ & $0,36 \%$ \\
\hline Kokaina & $33,33 \%$ & $66,67 \%$ & $1,60 \%$ \\
\hline Benzodiazepiny & $100 \%$ & $0,00 \%$ & $0,71 \%$ \\
\hline
\end{tabular}

9DTHC - 9delta-tetrahydrokannabinol; MDMA - 3,4-metylenodioksymetamfetamina 
we krwi wykryto 9 $\Delta$ THC. W wyniku wykonanej analizy toksykologicznej u 2,67\% (15) badanych wykryto metamfetaminę, MDMA stwierdzono u 2,14\% (12) badanych. Opioidy wykryto u $0,36 \%$ (2) badanych, kokainę - 1,60\% (9), benzodiazepiny $0,71 \%$ (4). Z uzyskanego stężenia 9 $\Delta$ THC wynika, że pod jego wpływem znajdowało się $57,26 \%$ (142) badanych, zaś 42,74\% (106) było w stanie po użyciu tego środka. Ocena stężeń amfetaminy wykrywanej we krwi kierowców wykazała, że pod jej wpływem było aż 88,26\% (233) badanych, a stan po jej użyciu stwierdzono u 11,74\% (31). W przypadku kierujących, u których wykryto metamfetaminę, stwierdzono, że 93,33\% (14) badanych znajdowało się pod wpływem, a 6,67\% (1) w stanie po użyciu (tab. 5).

Przedstawione dane za lata 2011-2015 wykazały, że w ocenianym okresie stopniowo, ale wyraźnie zmieniała się liczba przypadków dla dwóch najczęściej wykrywanych we krwi kierowców środków działających podobnie do alkoholu, tj. 9DTHC oraz amfetaminy. W 2011 r. i dwóch kolejnych latach 9 $\triangle \mathrm{THC}$ wykryto u ponad $80 \%$ badanych, natomiast w 2015 r. związek ten wykryto tylko u 44,13\% , a więc zdecydowanie najrzadziej w ocenianym okresie. Rozpatrując uzyskane wyniki w odniesieniu do stężenia amfetaminy od 2011 r., gdy ta substancja została wykryta u $16,43 \%$ badanych i był to najniższy udział procentowy w badanym okresie, zauważyć można, że następował stopniowy wzrost liczby kierowców, u których stwierdzono obecność amfetaminy. W 2015 r. amfetaminę wykryto u 46,98\% badanych, co w ocenianym okresie stanowiło najwyższy odsetek przypadków (ryc. 3).

\section{OMÓWIENIE WYNIKÓW I PODSUMOWANIE}

Przeprowadzona analiza statystyczna wyników uzyskanych dla próbek krwi zabezpieczonych od kierowców na terenie województwa zachodniopomorskiego w latach 2011-2015, a analizowanych w ZTKiS PUM, obejmowała wyłącznie badania pod kątem wykrywania środków działających podobnie do alkoholu. W analizowanym okresie przeprowadzono 3069 badań na zlecenie policji i prokuratury, uzyskując wynik dodatni

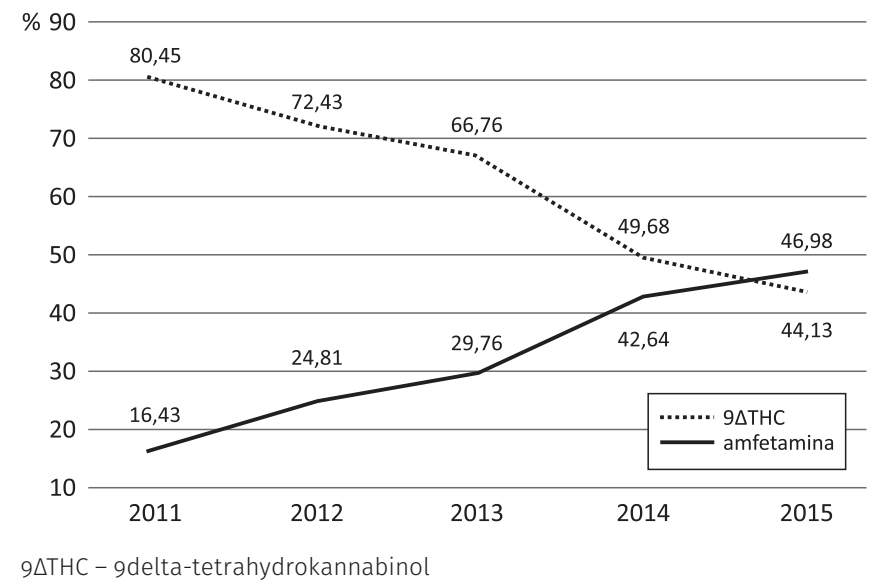

RYCINA 3. Procentowy udział wykrywanych substancji u kierowców w latach 2011-2015 w przypadku 2282 badanych, co stanowiło ponad $74 \%$ wszystkich badanych.

W analizowanym okresie zaobserwowano, że najczęściej wykrywanymi środkami działającymi podobnie do alkoholu były: $9 \Delta$ THC i amfetamina, przy czym statystyka dla obu związków diametralnie zmieniała się w ocenianym okresie. O ile 9 $\Delta$ THC był najczęściej wykrywanym związkiem w 2011 r., o tyle w 2015 r. jego udział procentowy zmalał blisko 2-krotnie. W odróżnieniu od amfetaminy i jej pochodnych, które w $2011 \mathrm{r}$. zostały wykryte w przypadku 16,43\% uczestników ruchu drogowego (najniższy poziom w badanym okresie), obserwowano coroczny stopniowy wzrost liczby kierowców znajdujących się pod wpływem amfetaminy.

W latach 2011-2012 we krwi kierowców nie stwierdzono obecności pochodnych amfetaminy (metamfetamina, MDMA), natomiast od 2013 r. stwierdzano obecność tych substancji w badanym materiale, jednak liczba potwierdzonych przypadków w porównaniu z liczbą kierowców, we krwi których wykryto amfetaminę oraz $9 \Delta \mathrm{THC}$, była nieznacząca. W odniesieniu do pozostałych środków działających podobnie do alkoholu (opioidy, kokaina, benzodiazepiny) odsetek kierowców, we krwi których wykryto te substancje, znajdował się w zasadzie na względnie stałym niskim poziomie. Najczęściej opioidy stwierdzano we krwi badanych kierowców w 2011 r. (1,98\%), najrzadziej w 2015 r. (0,36\%). Najwyższy odsetek kierowców, u których w badanym okresie stwierdzono obecność kokainy, nie przekroczył 2,00\%, gdzie najwyższy odsetek kierujących odnotowano w 2014 r. (1,71\%), a najniższy w 2011 r. (0,85\%). Podobne wyniki osiągano, badając pochodne benzodiazepiny. Najwyższy odsetek uczestników ruchu drogowego, u których stwierdzono obecność benzodiazepin, dotyczył 2014 r. (1,71\%), natomiast najniższy 2012 r. (0,25\%).

Odrębną kwestię, którą należy poruszyć w przypadku analizy statystycznej kierowców, we krwi których stwierdzono obecność środka działającego podobnie do alkoholu, jest określenie, czy taki kierujący w chwili zdarzenia znajdował się w stanie „po użyciu środka działającego podobnie do alkoholu” czy w „stanie pod wpływem środka odurzającego”. W ustawodawstwie polskim nie ma zapisów prawnych, które tak jak w przypadku alkoholu etylowego określałyby precyzyjnie zakresy stężeń dla omawianych związków w odniesieniu do analogicznego stanu po użyciu czy też stanu nietrzeźwości.

W przedstawionej pracy zastosowano kryteria przyjęte i używane w praktyce kazuistycznej. W 2012 r. podczas konferencji Toksykologów Sądowych w Krakowie przedstawiciele Instytutu Ekspertyz Sądowych (IES) zaprezentowali wyniki badań programu DRUID, który był prowadzony w 11 krajach europejskich, i zaproponowali polskie granice wartości stężeń środków działających podobnie do alkoholu w celu ustalenia stanu po użyciu i pod wpływem dla potrzeb opiniowania dla celów sądowych (tab. 6).

Opierając się na przedstawionych wytycznych, stwierdzono, że w latach 2011-2013 najwyższy odsetek kierowców (2011 - 80,45\%, 2012 - 72,43\%, 2013-66,76\%), znajdujących się w stanie po użyciu środka działającego podobnie do alkoholu lub pod wpływem środka odurzającego, stanowili kierowcy, 
TABELA 6. Zalecenia Instytutu Ekspertyz Sądowych dotyczące wartości dla stanów po użyciu oraz pod wpływem środków działających podobnie do alkoholu

\begin{tabular}{|c|c|c|c|}
\hline \multirow[t]{2}{*}{ Substancja } & \multirow{2}{*}{$\begin{array}{c}\text { Granice } \\
\text { analityczne } \\
\text { (ng/mL) }\end{array}$} & \multicolumn{2}{|c|}{$\begin{array}{l}\text { Wartości stężenia progowego } \\
\text { (ng/mL) dla stanu }\end{array}$} \\
\hline & & po użyciu & pod wpływem \\
\hline THC & 1 & $1-2,5$ & $\geq 2,5$ \\
\hline Amfetamina & 25 & $25-50$ & $\geq 50$ \\
\hline Kokaina & 10 & $10-20$ & $>20$ \\
\hline Benzoiloekgonina & 100 & $>100$ & nie ustalono \\
\hline Morfina & 10 & $10-20$ & $>25$ \\
\hline
\end{tabular}

THC - tetrahydrokannabinol

u których odkryto obecność 9 $\Delta$ THC. Natomiast w latach 20142015 odsetek kierowców znajdujących się w stanie po użyciu środka działającego podobnie do alkoholu lub pod wpływem środka odurzającego był już porównywalny dla obu związków (2014 r.: 9DTHC - 49,68\%, amfetamina - 42,64\%; 2015 r.: $9 \Delta \mathrm{THC}-44,13 \%$, amfetamina 46,98\%).

Przeprowadzona analiza statystyczna wykazała, że w analizowanym okresie liczba kierowców znajdujących się pod działaniem określonego środka działającego podobnie do alkoholu wzrastała z roku na rok, co wpływało na obniżenie bezpieczeństwa uczestników ruchu drogowego.

\section{PIŚMIENNICTWO}

1. Rozporządzenie Ministra Zdrowia z dnia 18 lipca 2014 r.

2. Drabek M, Andrysz A. Wpływ zażywania marihuany i amfetaminy (oraz jej pochodnych) na prowadzenie pojazdów na podstawie wyników badań symulatorowych. Med Pr 2011;62(5):551-63.

3. Gołembiowska K, Jurczak A, Kaminska K, Noworyta-Sokołowska K, Gorska A. Effect of some psychoactive drugs used as 'Legal Highs' on brain neurotransmitters. Neurotox Res 2016;29(3):394-407. doi: 10.1007/ s12640-015-9569-1.

4. Starmer GA, Vine JH, Watson TR. A co-ordinated approach to the drugs and traffic safety problem. Int J Psychopharm 1988;3(1):35-53.

5. Zacny JP, Virus RM, Woolverton WL. Tolerance and cross-tolerance to 3,4-methylenedioxymethamphetamine (MDMA), melhamphetamine and methylenedio-xyamphetamine. Pharmacol Biochem Behav 1990;35(3):637-42

6. Janus T, Machoy-Mokrzyńska A, Borowiak K. Genetic and molecular aspects of addiction with tetrahydrocannabinol. In: Preedy V, editor. Handbook of Cannabis and related pathologies. London: Faculty of Life Science and Medicine, King's Collegue; 2017. p. 713-21.

7. Potocka-Banaś B, Borowiak B, Janus T, Dembińska T, Rak A. Oznaczenie kokainy i jej metabolitów w surowicy krwi metodą chromatografii cieczowej sprzężonej z tandemową spektrometrią masową (LC-MS/MS). Diagn Lab 2016;52(2):85-94.

8. Borowiak K, Potocka B, Sajdak R. Monitorowanie środków stosowanych w premedykacji i analgezji pooperacyjnej u pacjentów chirurgicznych luksus czy potrzeba? Anest Intens Ter 2002;34(1):9-13.

9. Potocka-Banaś B, Dembińska T, Borowiak K. Ocena wydajności różnych metod izolacji wybranych pochodnych benzodiazepiny z krwi pełnej i surowicy krwi ludzkiej oraz zjawisko ich reaktywności w metodzie immunoenzymatycznej. Diagn Lab 2016;52(2):107-114. 